\title{
Urbanization: concepts, trends and analysis in three Latin American cities
}

\section{Abstract}

Explanatory models on the urban expansion process have focussed mainly on the dynamic of cities in the developed countries that are characterized by a strong institutional framework, a culture of urban planning, and compliance with the rules. This paper analyses the phenomenon of urban expansion in three Latin American cities (Buenos Aires, Santiago de Chile and Mexico City), taking into account cities with a strong process of urbanization and where the local administration does not have enough control over the growth of cities due to the high rate of migration determining sub-urbanization, peri-urbanization, exourbanization, and counter-urbanization processes similar to developed countries. However, these processes may be related to hidden or displaced urbanization in rural areas of municipalities and metropolitan areas or intermediate cities due to the dynamics of urban consolidation. In every Latin American country, the participation and combination of these phenomena are different, although the results are similar: the advance of urban expansion with more segmented, disperse and distant patterns of large urban centres. This analysis determine the characteristics of the urbanization process taking into account physical and geographic aspects, urbanization trends and socioeconomic features in cities selected of Latin America and determines their impact determining the importance to formulate adequate policies that integrates environmental and socioeconomic aspects to achieve sustainable development in urban contexts.

Keywords

Urbanization • Latin American cities • urban sprawl • suburbanization • peri-urbanization

(C) University of Warsaw - Faculty of Geography and Regional Studies
William Alfonso Piña

Faculty of Science Policy and Governmen Urban Development and Management Program Universidad del Rosario

Bogotá

e-mail:william.alfonso@urosario.edu.co

\section{Introduction}

The most urbanized region in the world is Latin America with almost $80 \%$ of its population living in cities, although it is also one of the least populated in relation to its territory (UN-Habitat 2012). In this region, population growth and urbanization were previously accelerating but these processes are now decelerating. Currently, the evolution of urban populations tends to be limited to natural growth characterized only by an increment of migration between cities, the growth of secondary cities, and the emergence of mega-regions and urban corridors (UN-Habitat 2012).

Urban development in this region cannot be described by place-to-place differences in ecological location, population composition, economic growth, employment or income inequality. In general, rural areas in Latin America are considered merely as surrounding areas, whereas, cities and large urban agglomerations are the control centres and urban areas grow significantly at the expense of the rural soil. Several Latin American cities have transformed dramatically due to fast and sometimes forceful processes of urbanization characterized by a deterioration of the environment and social inequality.

Latin American cities face an important challenge in the next decades for this region to achieve improvements of the welfare of urban population through more quality, equity, and sustainability in the region, evading again the cycle of underdevelopment, inequality, and unsustainability that has been a feature in recent decades. It must be taken into account that they the population is expected to increase to 604 million and the percentage of total population living in urban areas will constitute $83 \%$ of the total population by 2030 . (UN-Habitat 2012). In this context, it is important to determine and analyse the trends of urbanization in Latin American cities with the aim of determining previous patterns and to formulate new policies that will allow an adequate urban development model, taking into account the different features in the cities of the region.

Latin American studies on urbanization trends have analysed different approaches - for example, Inestroza et al. (2013) characterized urban development and sprawling features for 10 Latin American cities using the GIS tool, determining that there is an underlying fragmentation trend towards increasing sprawl. Cordoba \& Gago (2010) evaluated changes in urban Latin American systems in the context of the acceleration of globalisation processes, calculating diverse indicators of connectivity to assess a longitudinal analysis and confirming the contradictory effects of globalisation which cannot only generate opportunities but also aggravate social and territorial inequalities. Dufour \& 
Piperata (2004) determined the biological consequences of ruralto-urban migration in Latin America using qualitative techniques suggesting the physical environment might have a greater impact on health than migrant status, except for the initial stage of urban residency; focussing on the heterogeneity of urban environments should be a productive research strategy. Poelhekke (2011) modelled rural-urban migration with an econometric model, determining that countries can urbanize surprisingly quickly even when economic growth is slow or negative. Klaufus (2010) addressed urban sprawl in two intermediate cities in Central America (Quetzaltenango in Guatemala and San Miguel in El Salvador) and explored current urbanization trends in relation to transnational migration, remittances and related manifestations of globalization with qualitative analysis, determining that suburban disorder is attributed to fully serviced residential projects for a new middle class, built on ecologically vulnerable land. These studies have characterized the specific process in Latin America determining the diverse relationship between urbanization, environment, and population.

Other studies have analysed urbanization trends in specific cities in Latin America - for example, Rojas et al. (2013) studied the Metropolitan Area of Concepción (Chile) using a method based on the land Suitability Index (LSI) and a cartographic GIS to determine the suitability of each point in a region for urban development, suggesting that the planned urban growth is highly unsustainable since the new urban areas will necessarily occupy lands that require protection because they are susceptible or sensitive to natural risks. Bayón \& Saravi (2012) evaluated urban fragmentation in Mexico City from the perspective of the relationship between urban space and social space and the effects of fragmentation on inequality and social cohesion, finding that the scale of urban segregation is decreasing and sociocultural dimensions in the city address a new geography of urban inequality that undermines social cohesion. Licinio et al. (2013) constructed a high resolution radiometric map with a Geographic Information System for the City of Rio de Janeiro to determine changes in urbanization, finding that the urban population have different risks in this city. These studies have analysed urbanization trends using specific methods to determine their effects on the environment and population.

However, despite the valuable contributions of previous studies, the analysis of the urbanization process - taking into account physical and geographic characteristics, urbanization trends and social aspects to determine sub-urbanization and peri-urbanizaton processes - is limited in the context of the cities selected (Buenos Aires, Santiago de Chile and Mexico City). These are considered megacities of Latin America with an urban growth characterized as rapid, dispersed and with limitations in planning. An evaluation of these characteristics and trends should better explain the phenomenon of urban expansion from the centre to periphery due to the dynamics of urban consolidation. The main objective of this study is to determine and characterize the processes of urbanization in particular cities in Latin America, such as Buenos Aires, Santiago de Chile and Mexico City. For that purpose, we use several indicators with the aim of defining and distinguishing between urban processes of recent years.

The paper is divided into six sections. Following this brief introduction, the second section gives a literature review and the main definitions of urban processes. The third section describes methods, indicators, and data used in this study. Section four shows the main results and discussion for the cities selected. In section five, we finally draw some conclusions.

\section{Literature review}

In Latin America, the general trends of a city framework show four stages: 1 . The colonial city, as a compact city (1820); 2. The first stage of urbanization, as a sectoral city influenced by
European migration (1920); 3. The second stage of urbanization as a polarized city, characterized by internal migration from rural to urban areas (1970); and 4. The current city, characterized as a fragmented city (2000). In these stages, the cities changed from a compact body within a sectorial perimeter to a fragmented city (Hidalgo \& Borsdorf 2009).

In Latin American cities, the new approaches to overcoming distances are the basic conditions for changing lifestyles and the new demands of environmental equipment and housing, which nowadays are developing more slowly in several of the main cities than in the periphery. Hence, outlying areas of large cities are more dynamic than central areas (Panreiter 2004). To understand the urban phenomenon in this region from features of its growth, it is important to define the terminology used, taking into account different features of urban expansion and geography of urban conditions (Pacione 2009). Table 1 shows the main definitions of spatial processes related to urbanization in recent decades.

Table 1 summarizes some aspects of sub-urbanization and peri-urbanization conventional processes, which in the Latin American context correspond to stages of urban expansion phenomena, which have modified the urban agglomeration dynamic and city systems where, according to the data, a hidden urbanization process may be present.

The dynamic of urban expansion and land occupation patterns in Latin America have not been a static process. In contrast, some sub-urbanization and counter-urbanization processes are predecessors of urban settlements with a high level of urbanization. These processes are focalised by aspects such as scale, nature and functioning of geographical bases, territorial and management systems, regulations and requirements and different mechanisms of formal and informal management promoting urban growth.

Latin American cities also show exo-urbanization, suburbanization, and peri-urbanization processes, both formal and informal, where the expanding urban development is characterized by disperse patterns for first and second housing, consolidating a dense urban zone, changes promoted by technological advances such as road connectivity, telecommunications, service infrastructure, variations in population structure, and increase in public purchasing power (Gans 2007; Ferras 2007; Alfonso \& Pardo 2014).

Urbanization is an extreme case of a change in land use and is associated with the reduction of green areas and the increase of impermeable surfaces, which have a significant impact on local climate by reducing humidity and increasing average temperatures in the area. Moreover, the increase of emissions of pollutants and greenhouse gases (GHG) has a direct effect on air pollution and an indirect effect on the mixing layer in cities (Bochaca \& Puliafito 2007, Pacione 2009). Figure 1 describes the expanding urban development for more remote locations, less impacted by the displacement of agriculture and tourist uses that once generated the "higher usability" of land. This was promoted by property conditions in Latin America consolidating the structure of urban systems and variations in the configuration of metropolitan areas (internal and surroundings). These preferences are a product of the concept that quality of life is associated with rural surroundings and the advantages of being close to the centre, to provide services and generate employment.

\section{Methods and Data}

This study seeks to describe urban dynamics and provide a trend analysis of the changes in urban processes in three Latin American cities (Buenos Aires, Santiago de Chile and Mexico City), analysing three aspects: 1. Physical and geographic characteristics to determine geographic situation and localization, landscapes, soils, geology and environmental resources; 2. Urbanization trends to describe the growth of the cities studied in 
Table 1. Urban growth - main definitions

\begin{tabular}{|c|c|c|c|c|c|c|c|}
\hline & $\begin{array}{l}\text { Sub- } \\
\text { urbia }\end{array}$ & $\begin{array}{c}\text { Peri- } \\
\text { urbanization }\end{array}$ & $\begin{array}{l}\text { Post- } \\
\text { suburbia }\end{array}$ & $\begin{array}{c}\text { Ex- } \\
\text { urbanization }\end{array}$ & $\begin{array}{c}\text { Counter- } \\
\text { urbanization }\end{array}$ & $\begin{array}{l}\text { Desurba- } \\
\text { nization }\end{array}$ & $\begin{array}{l}\text { Edge } \\
\text { City }\end{array}$ \\
\hline $\begin{array}{c}\text { Relationship } \\
\text { with traditional } \\
\text { centre of the city }\end{array}$ & Strong & $\begin{array}{l}\text { Still } \\
\text { strong }\end{array}$ & Weak & Strong & $\begin{array}{l}\text { Still } \\
\text { strong }\end{array}$ & Weak & $\begin{array}{l}\text { Very } \\
\text { Weak }\end{array}$ \\
\hline $\begin{array}{c}\text { Distance to } \\
\text { traditional centre } \\
\text { of the city }\end{array}$ & Short & Medium & Medium & $\begin{array}{l}\text { Medium to } \\
\text { large }\end{array}$ & $\begin{array}{l}\text { Medium to } \\
\text { large }\end{array}$ & Large & Large \\
\hline $\begin{array}{l}\text { Pendular } \\
\text { migration }\end{array}$ & $\begin{array}{l}\text { Daily } \\
\text { migration }\end{array}$ & $\begin{array}{l}\text { Daily } \\
\text { migration }\end{array}$ & In equilibrium & $\begin{array}{l}\text { Daily } \\
\text { migration }\end{array}$ & $\begin{array}{l}\text { Daily } \\
\text { migration }\end{array}$ & Without & $\begin{array}{l}\text { Daily } \\
\text { migration }\end{array}$ \\
\hline Centrality & Without & Without & $\begin{array}{c}\text { From } \\
\text { individual } \\
\text { functions to } \\
\text { middle and } \\
\text { high }\end{array}$ & Without & Without & - & High \\
\hline $\begin{array}{c}\text { Losses for } \\
\text { traditional centre } \\
\text { of the city }\end{array}$ & Without & Population & $\begin{array}{l}\text { Population } \\
\quad \text { and } \\
\text { workplaces }\end{array}$ & Population & $\begin{array}{l}\text { Population } \\
\quad \text { and } \\
\text { workplaces }\end{array}$ & Population & $\begin{array}{l}\text { Population } \\
\quad \text { and } \\
\text { workplaces }\end{array}$ \\
\hline $\begin{array}{l}\text { Motivating force } \\
\text { for mobility }\end{array}$ & $\begin{array}{l}\text { Low cost } \\
\text { housing }\end{array}$ & $\begin{array}{l}\text { Low cost } \\
\text { housing }\end{array}$ & $\begin{array}{l}\text { Style and } \\
\text { quality } \\
\text { of life }\end{array}$ & $\begin{array}{l}\text { Quality } \\
\text { of life }\end{array}$ & $\begin{array}{l}\text { Accessibility } \\
\text { and quality } \\
\text { of life }\end{array}$ & $\begin{array}{c}\text { Competitive } \\
\text { advantages } \\
\text { for } \\
\text { companies }\end{array}$ & $\begin{array}{l}\text { Competitive } \\
\text { advantages } \\
\text { for } \\
\text { companies }\end{array}$ \\
\hline References & $\begin{array}{l}\text { Banzhaf et } \\
\text { al., 2013. In } \\
\text { Santiago de } \\
\text { Chile }\end{array}$ & $\begin{array}{l}\text { Aguilar, } 2008 . \\
\text { In Mexico City }\end{array}$ & $\begin{array}{l}\text { Borsdorf, } \\
\text { 2004. In the } \\
\text { European } \\
\text { cities }\end{array}$ & $\begin{array}{l}\text { Clark et al., } \\
\text { 2009. In USA }\end{array}$ & $\begin{array}{l}\text { Bijker and } \\
\text { Haartsen, } \\
\text { 2012. In } \\
\text { Netherlands }\end{array}$ & $\begin{array}{l}\text { Osada, } \\
\text { 2003. In } \\
\text { japan }\end{array}$ & $\begin{array}{l}\text { Garreau, } \\
\text { 1991. In the } \\
\text { context of } \\
\text { USA. }\end{array}$ \\
\hline
\end{tabular}

Note. The data are from (Hidalgo \& Borsdorf 2009)
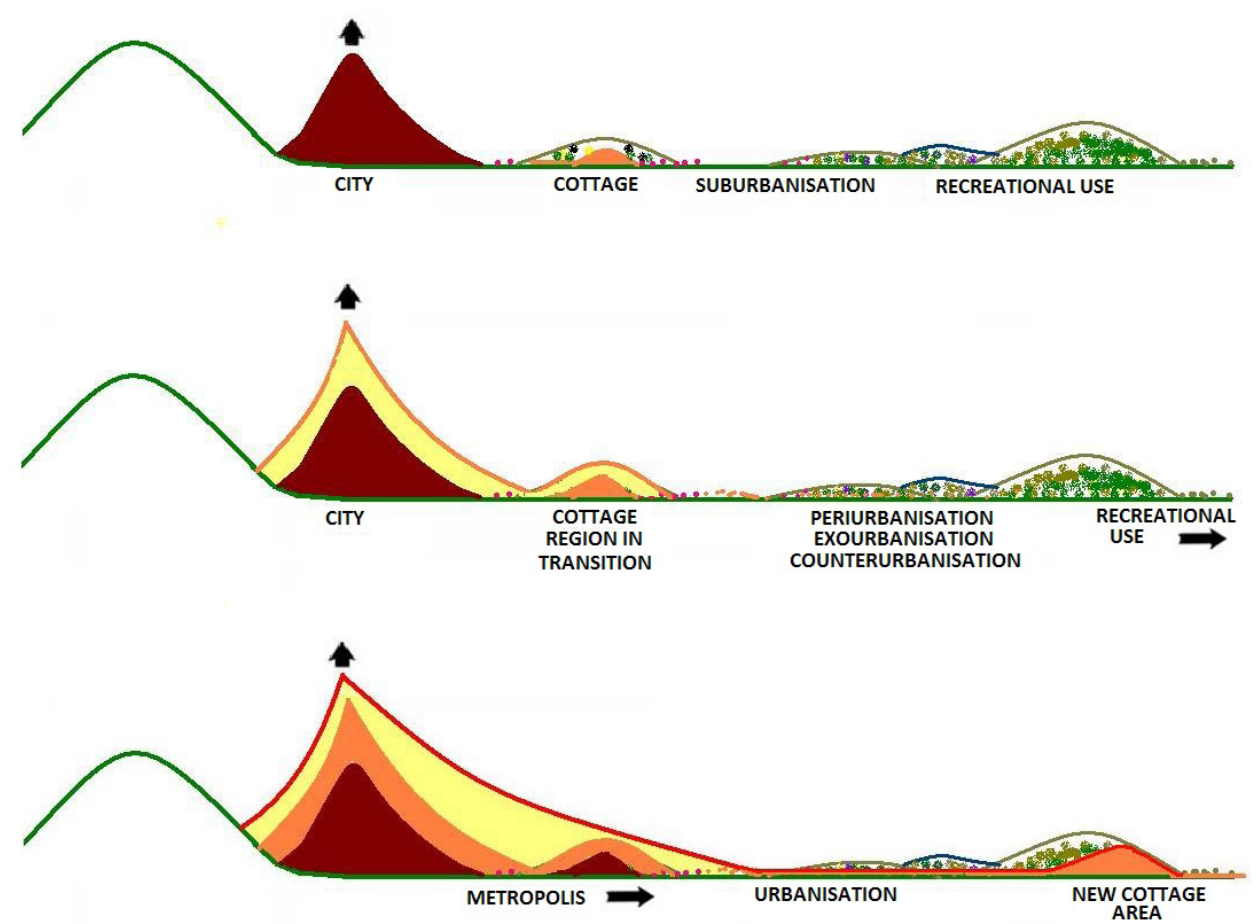

Figure 1. Urban expansion in the Latin American hinterland context Urban Suburban Urban Growth Note. The data are from: (Lundgren 1974, p. 129). 
recent decades through density, amount of occupied ground and persons per spatial unit (hectare); and 3. Socioeconomic aspects to analyse the relationship between urbanization, poverty, urban population in slums, gross domestic product and new constructions. These aspects with their variables allow the determination of features of the urban system, adaptation of patterns, geographical factors, and special aspects of settlements such as expansion, development and environmental conditions, among others.

For each city selected, certain attributes are analysed, such as: urban density (measured as persons per hectare), distribution of population in the centre and periphery of the city (measured as percentage), estimations for persons per household and households per hectare with the aim of establishing the consolidation phenomena of suburban zones, the population living in slums (measured as percentage of urban population living in slums), poverty (measured as percentage of population), change in urban agglomerations (measured as average annual rate); gross domestic product and gross domestic product of construction (measured as annual rate of change), new buildings and extensions (measured as square meters $\left(\mathrm{m}^{2}\right)$ ), features of metropolitan areas, and the comparison of several indicators, with the aim of determining the urbanization process in every city selected. The main data sources used in this study to calculate variables for the three cities come from each city's respective statistics offices and the CEPAL database.

\section{Results and discussion}

This section shows the analysis of Latin American cities selected for this study with the aim of describing the urbanization process according to certain indicators, taking into account available data as explained in the previous section.

\section{Buenos Aires (Argentina)}

Physical and geographic characteristics

Buenos Aires is situated on the banks of the Rio de la Plata, an estuary derived from the confluence of the Parana and Uruguay Rivers, where they flow into the Atlantic Ocean. These mighty rivers transport vast amounts of sediments, which is why there are so many clay and mud banks in the estuary. The enormous sedimentation capacity of the Rio de la Plata has greatly influenced the urban development of this city and the particular way in which the coast has been used which, in turn, explicates the characteristics of its man-made heritage.

This city stands on a plain of sedimentary origin that overlays a rocky platform. The sediments are of a diverse nature: some are coarse (sand) and others are finer (clay and mud). They have reached the plain after having been carried by different means - the heaviest by sea, as the Pampean plain was occupied by the sea during earlier geological periods. Buenos Aires opted for a mobile coastline, where the successive sedimentation processes have generated different forms of usage of the new spaces. At each historical stage, new forms of use of the lowlying lands were defined, in accordance with the city-planning and architectural fashions of the day. Although they display a wide range of morphological differences, what most of them had in common was to consider the limit between the City and the Rio de la Plata as a space that was not defined once and for all but in a continuous process of change (Nieves 2006).

The particular natural conditions of continuous sedimentation of the estuary generated diverse constructive forms that characterized Buenos Aires over time, with several historic layers, representative of the styles of each period. Unlike the archaeological zones, in which the layers are vertical (the new upon the old), in Buenos Aires we find horizontal layers, where the oldest are on the historical edge of the river bank and the newest are near the present water's edge.
The slope is the geological formation that best describes the change in landscape between the flat land and the coastline with the Rio de la Plata. The coastline and the Rio de la Plata, although currently having different environments, are genetically closely related, the coast in particular being the zone that has experienced the greatest changes and where the dynamics of the interaction of man and nature are most conspicuous (Nieves 2006).

\section{Urbanization trends}

The development of the City of Buenos Aires as a whole was the result of a public project during the 1980s. Urban planning by means of "The Square" ("La Cuadrícula") allowed the city to expand endlessly and was the matrix in which urban development and social advancement were installed (Gorelik 1998).

In the 1930s, the city built the "General Paz Avenue" which completely surrounded the City of Buenos Aires, and public plot division started to be developed in the suburbs. In a way, this "off-wall" urbanization is similar to the pavillonnaires suburban neighbourhoods (small house plots) of Paris between the war periods (Fourcaut 1996). Urbanization is the result of a mix between "laisser faire" and public intervention policies, between square plotting as well as self-construction and self-urbanization bricolage. Thus, this kind of urban growth has allowed largescale access to property and house ownership. That was made possible due to a series of government policies (suburban transportation subsidies, low rate mortgages and unrestrictive legislation) and to the joint action of inhabitants (Torres 1993).

After the 70's, promoters stopped plotting for low-income sections. In the 80 's, big changes in poverty specialization occurred, both in the capital city and the suburbs. For a long time, the terms "slums," or "shantytowns" were the words used to describe the poverty problem, providing a dual side to the whole city. However, poverty today cannot be thought of in terms of "specific localization", but in terms of "relative degree", as a phenomenon that is expanding and trespassing borders between neighbourhoods and even small isolated urban areas (FB, 2008).

Hence, The Buenos Aires metropolitan area becomes the third largest urban region in Latin America (12.6 million inhabitants in $8,000 \mathrm{sq}$. $\mathrm{km}$.); this mega-city has shown a tendency towards peripheral development for segregated housing expansions for the middle- and high-income population, which has generated an explosive and non-planned urbanization process. This situation is characterized by problems related to urban sustainability such as constraints in housing, sewerage, provision of water and energy, rubbish disposal, and lack or inaccessibility of transportation centres, as well as education and health services that result in urban poverty and violence (UN-Habitat 2012; Leston 2005).

From the geographical perspective, according to Virgilio \& Vio (2009), the metropolitan area of Buenos Aires has three sectors: the centre of the region that is the central area of the city of Buenos Aires; the suburban area, limited by the edge of the central area and the edge of suburban area, denominated as the Greater Buenos Aires; finally, the periphery region.

The metropolitan area of Buenos Aires has a surface area of $13943 \mathrm{~km}^{2}$. The most recent census data from Buenos Aires shows that the central area holds $21 \%$ of the population, the suburban area $66 \%$, and the periphery $13 \%$, which demonstrates that the population has moved from the central area to the suburban area (especially the population with middle- and high-income). Therefore, the agglomeration is extended, with a new logic of structuration of the metropolitan space characterized by new centralities that weaken traditional urban patterns and centralities.

Over the last decade, urban density (measured as persons per hectare) has shown a near-constant trend in Buenos Aires (see Fig. 2), indicating that suburban areas and the periphery have become more concentrated and attract more conglomerates. 


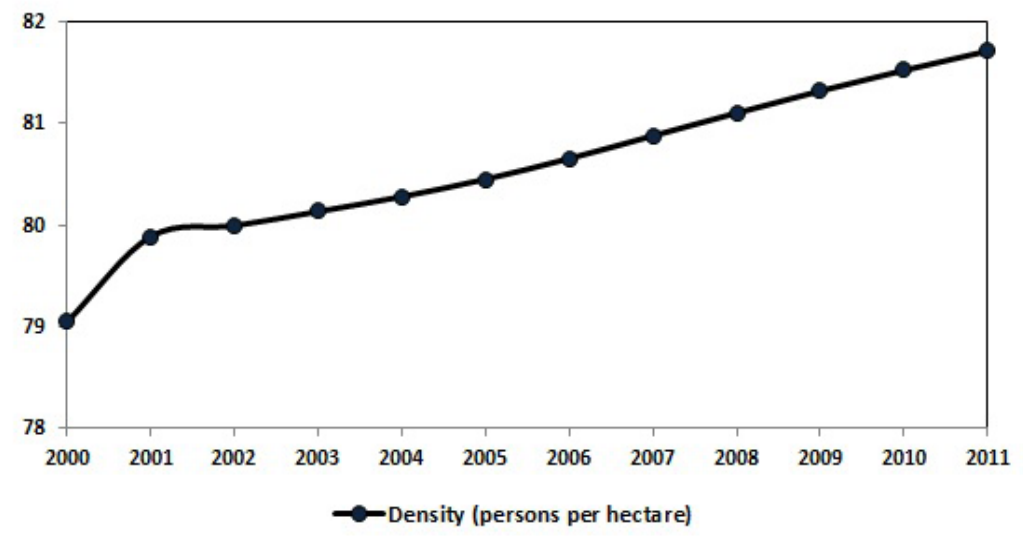

Figure 2. Buenos Aires - Urban Density 2000-2011

Source: GCBA, 2011

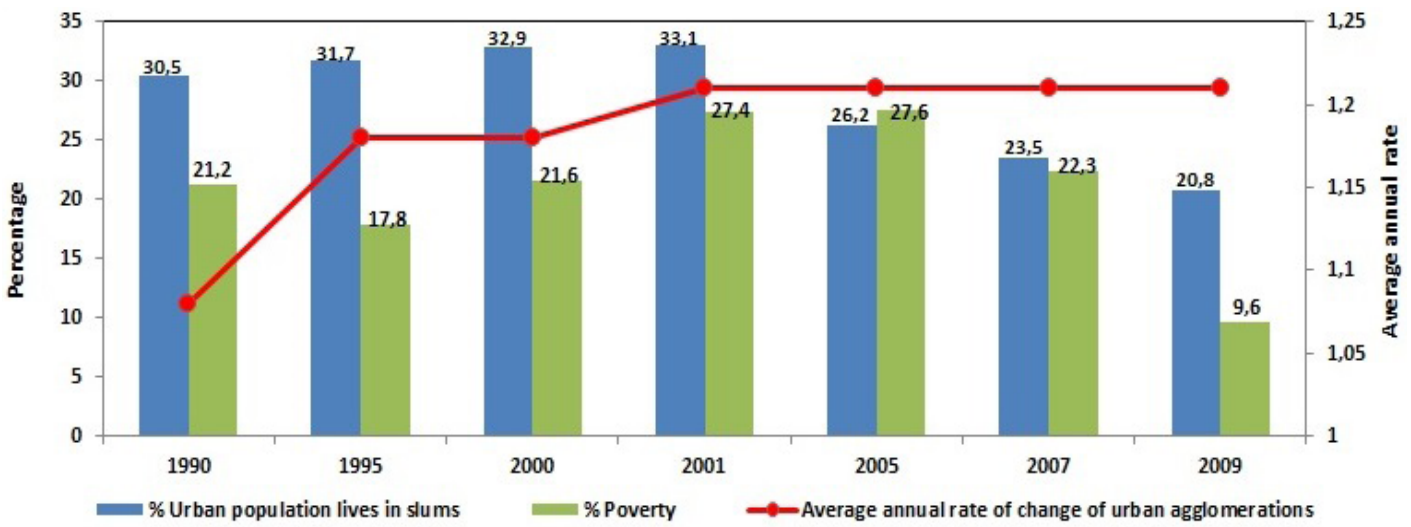

Figure 3. Buenos Aires - Slums, poverty and urban rate change Source: CEPAL Database 2014

The increase of urban density demonstrates the consolidation phenomena of suburban zones as urban areas: 81 persons per ha supposes 3.3 persons per household and 25 households per hectare, a measurement considered as urban area. The process begins with rural land subdivision, for single family country homes, and continues transforming, through incremental subdivision, into high density developments on unserviced land.

\section{Urbanization and socioeconomic aspects}

In Buenos Aires, the population living in slums in the city grew from 107,000 persons (2001) to 170,000 (2010). Fifty percent of the inhabitants are immigrants who belong to neighbouring countries (Paraguayans, Bolivians and Peruvians). In 2005, 25\% of this population were tenants (Cravino 2006), but in 2010 the percentage of tenants reached $40 \%$ of the population of these neighborhoods. Simultaneously, room rental in the slums was boosted by $600 \%$, at a rate above inflation (Cravino 2010).

Figure 3 show the trends of urban population living in slums, poverty and average annual rate of urban agglomeration in recent decades. It indicates a direct relationship between poverty and population living in slums, whereas the average annual rate of urban agglomeration tended to stabilise during this period. Slums in this city are characterized by highly crowded concentrations in which there are no roads, but pathways, with vertical growth, far more difficult to urbanize, and located in the peripheral rings, which is denominated periurbanization. Moreover, these settlements have a large deficit regarding access to basic services and inadequate urban infrastructure for different sectors of the community; it is important to formulate an adequate housing policy that contributes to improving living standards.

Figure 4 shows the main indicators of gross domestic product and urbanization in Buenos Aires. In this city gross domestic product per capita and gross domestic product of construction have similar trends whereas new buildings and extensions grew in the first years of the decade. At the end of the decade a decrease in this indicator began, demonstrating that the economy and urbanization have a similar or direct relationship.

\section{Santiago de Chile}

Physical and geographic characteristics

Santiago de Chile is located in the nation's fertile central valley and is encircled by mountain chains. The most prominent of these are the Andes, situated to the north and the east of the city. Moreover, this city lies in the center of the Santiago Basin, an enormous bowl-shaped valley consisting of a broad and fertile plain surrounded by mountains. It is flanked by the main chain of the Andes to the east and the Chilean Coastal Range to the west. To the north, it is bounded by the Cordón de Chacabuco, a transverse mountain range of the Andes, whereas at the southern border lies Angostura de Paine, a valley narrowing where an elongated spur of the Andes reaches nearly to the Coastal Range. The Santiago Basin is part of the Intermediate Depression and is remarkably flat, interrupted only by a few hills.

The city is built in the Central or Intermediate Depression, which is a basin replenished mainly by alluvial and fluvial sediments and, in a minor proportion, by material associated 
MISCELLANEA GEOGRAPHICA - REGIONAL STUDIES ON DEVELOPMENT

Vol. $18 \cdot$ No. $3 \cdot 2014 \cdot$ pp. 5-15 • ISSN: 2084-6118 • DOI: 10.2478/mgrsd-2014-0020

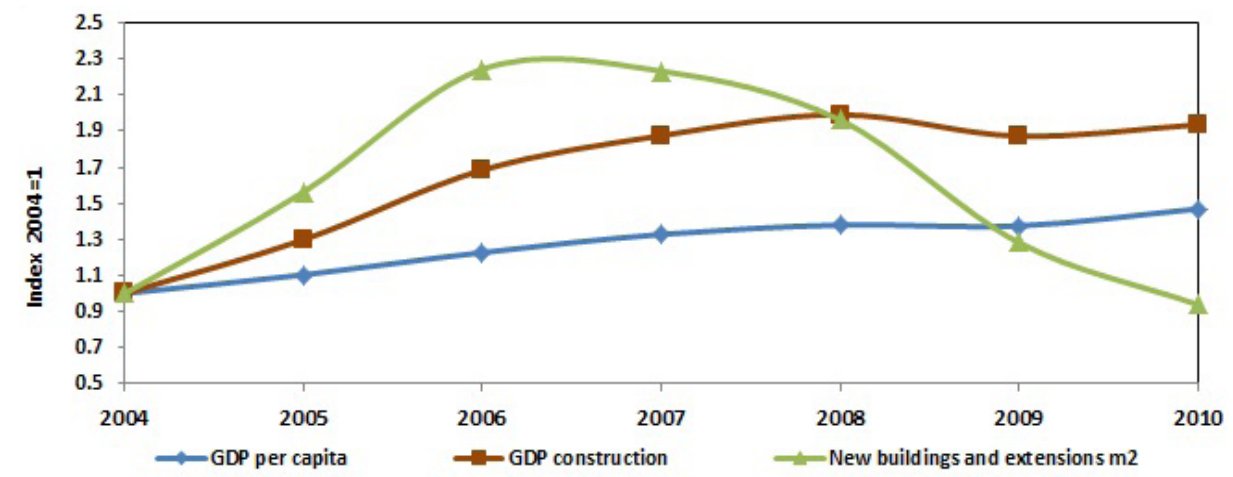

Figure 4. Buenos Aires - Gross domestic products and new buildings and extensions Source: CEPAL Database 2014

Table 2. Changes in urban patterns in Santiago de Chile

\begin{tabular}{|c|c|c|c|}
\hline Features & $\mathbf{2 0 0 1}$ & $\mathbf{2 0 0 9}$ & $\%$ Variation \\
\hline Dense built-up area & 17110 & 14176 & $-17.15 \%$ \\
\hline $\begin{array}{c}\text { Intermediate built-up } \\
\text { area }\end{array}$ & 39676 & 48741 & $22.85 \%$ \\
\hline Dispersed built-up area & 13342 & 14406 & $7.97 \%$ \\
\hline $\begin{array}{c}\text { Green spaces within } \\
\text { urban areas }\end{array}$ & 10814 & 10373 & $-4.08 \%$ \\
\hline
\end{tabular}

Source: Krellenberg et al. 2013

with volcanic activity. The Central Depression constitutes a northsouth trending morphological structural unit located between the Coastal Cordillera, to the west, and the Andes Main Cordillera, to the east. This pattern would have been generated during a maximum compression phase during the Upper Oligocene Middle Pliocene (Thiele 1980), related to the subduction tectonic regime that has dominated the region since the Jurassic (Thomas 1958). The origin of this basin has been considered tectonic, delimited by north-south trending faults, particularly to the east (Brüggen 1950; Borde 1966).

The Central Depression at the latitude of Santiago includes four soil units of alluvial, fluvial and volcanic origin with different geotechnical characteristics. The north-western part of the valley is dominated by alluvial silt and high plasticity clay soils deposited by the Lampa and Colina creeks (Valenzuela 1978). Some of these soil formations display swelling problems and shallow water tables, causing problems for foundation design and flooding hazards.

The city centre and most of the older parts of the city are situated on fluvial deposits informally called Santiago Gravel. This soil is composed of boulders usually less than $20 \mathrm{~cm}$ in diameter in a matrix that varies from silty gravel to silty sand, with sandy and clayey lenses. The soil has a high density, low deformability and good geotechnical properties for construction (Valenzuela 1978). The soil originates in the deposits of the Mapocho and Maipo Rivers, grading to coarser deposits closer to the apex of the rivers' alluvial fans, to the northeast and southeast, respectively. The eastern part of the valley is mainly dominated by the alluvial fans of the ravines that drain the San Ramón range. These soils are composed by rock blocks in a silty and clayey matrix with varying amounts of sand, deposited by alluvial and hillslope processes, and present heterogeneous geotechnical properties: nearer to the mountain foothills, the materials are coarser and more heterogeneous, while in the distal zones they tend to be more stratified and homogeneous in texture and granulometry (Valenzuela 1978). Similar deposits of smaller extension are situated in the foothills of the Coastal Cordillera, on the western edge of the city (Fernández 2001).

\section{Urbanization trends}

In recent decades, Santiago de Chile has been characterized by a very rapid urbanization patterns attributed to megacities and the growing demand for land where intermediate and dispersed built up areas have increased, whereas green spaces within urban areas have decreased (see Table 2). This metropolitan area is home to more than six million inhabitants or about 40 per cent of Chile's national population (INE 2011). While in previous decades urban expansion advanced principally on flat areas situated on the alluvial floodplains of the Mapocho and Maipo rivers, in the last decade urban sprawl has progressed up into the Andean piedmont (Romero \& Ordenes 2004).

In Santiago de Chile, the dynamic nature of social housing construction tends to be located in areas where land is cheaper in the urban periphery, characterized by poorly connected and poorly served areas. Moreover, the deregulation of new urban areas and a lack of coordinated land and housing policies have contributed to disproportionate land price increases on the urban peripheries (UNABITAT 2012).

In this city the urbanization process has been influenced by environmental factors such as better air quality, found above 850 $\mathrm{m}$ where the top of the thermal inversion layers are located, which was a motive for the upper classes to escape polluted areas at lower altitudes. Landscape quality - in terms of landscape, vegetation and clear skies - has generated a continuing effect for the urbanization of mountainous areas, characterized by private housing developments, gated communities especially built for the richest people, with some remaining poor people who previously illegally occupied the area (Romero \& Ordenes 2004). Therefore, the growth of the city, planned as well as informal, decreases valuable open spaces, for example, and increases the degree of impervious surfaces. As a consequence, the potential for flood hazards becoming risks or disasters is increasing due to, for example, the reduction of retention areas for flooding, building activities on the peri-urban piedmont or the clearing of avalanche forests in mountain regions. The changes in land use also cause an increase in the number of people living in hazard prone areas and increasing surface runoff, decreasing groundwater recharge, and polluted water sources (Weiland et al. 2011).

Urban density in Santiago de Chile is almost 115 inhabitants per hectare, showing an increase in the last decade (see Fig. 5) due to regional in-migration. Likewise, the number of households has 


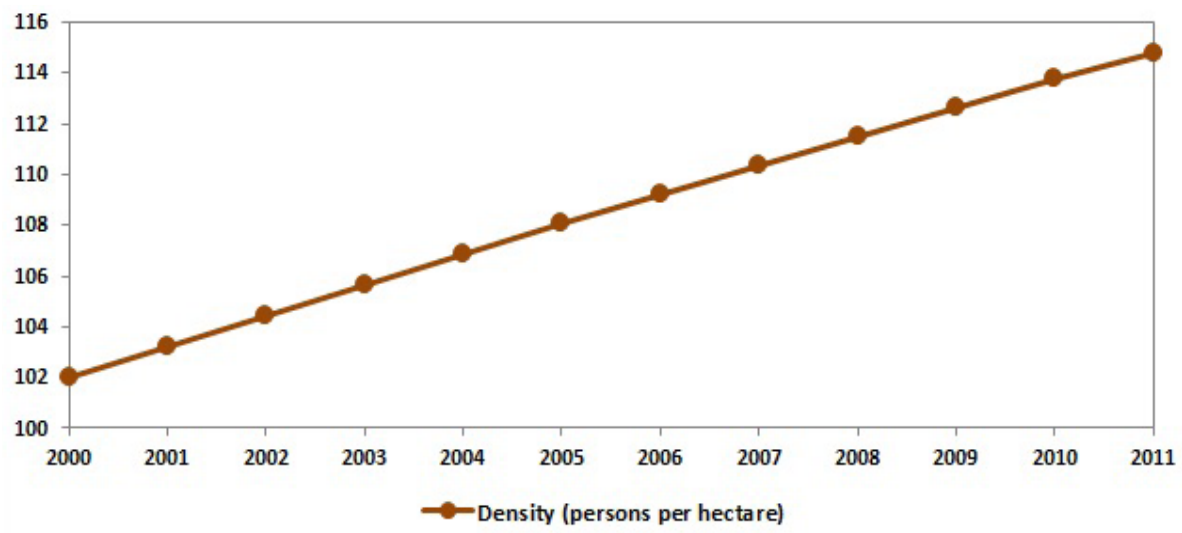

Figure 5. Santiago de Chile - Urban density 2000-2011

Source: INE, 2011

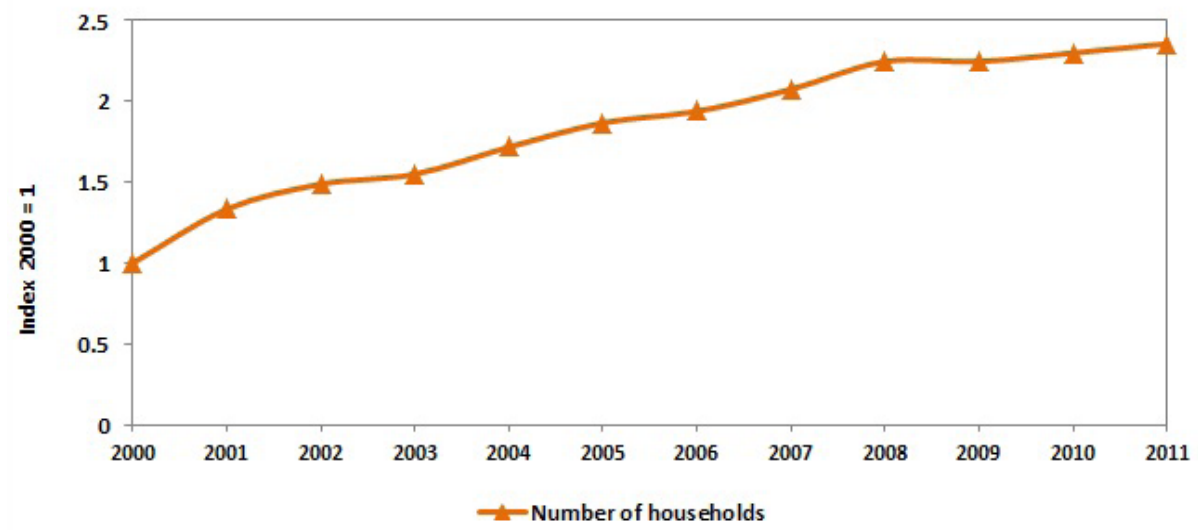

Figure 6. Santiago de Chile - Number of households 2000-2011 (Index: $2000=1$ )

Source: INE, 2011

more than doubled in the last decade (see Fig. 6). These indicators show the urban dynamics in this city which have generated exclusion and social segregation, characterized by municipalities that corresponded to a specific socio-economic group and physical distance from the city centre. From the environmental perspective, the rich population resides in areas of better air quality with more amenities and urban facilities and higher security against risks and natural hazards. Conversely, the poorest social groups reside in areas with lower environmental services and environmental quality, demonstrating inequality in environmental services and more natural hazards (Romero et al. 2012).

In this city, according to estimates, a dwelling has on average 3.5 persons; 32.8 households per hectare define that it is not a sub-urban pattern due to the fact that it exceeds the measurement of 25 households per hectare.

Figure 6 shows the increase of households per unit of land, which in popular zones exceed 2.3 dwellings - this could increase with the estimated population density per hectare.

\section{Urbanization and socioeconomic aspects}

In Santiago de Chile, throughout the 1990s and 2000s, the number of shantytowns and slums reduced every year and more families were becoming home owners. An average of 90,000 families a year achieved a subsidy during these years (MHUA 2006). In 2006, after 16 years of left-of-centre governments, shantytowns and slums were almost a thing of the past: only around 120,000 people were living in shantytowns (CSR 2007), and no more than 60,000 people were homeless, totaling around
$1.5 \%$ of the country's population. These results concur with a decrease in poverty from $32.1 \%$ in 1990 to $8.7 \%$ in 2009 (Cepal 2014), which demonstrates the importance of improving human settlements as a strategy to increase sustainability development and decrease poverty with adequate infrastructure and facilities.

Moreover, gross domestic product per capita, gross domestic product of construction and new buildings and extensions in the first years of the decade showed a similar trend, whereas in the middle of the 2000s new buildings and extensions increased and then decreased at the end of the decade (see figure 7), demonstrating that economy growth is an important aspect in the urbanization process.

\section{Mexico City \\ Physical and geographic characteristics}

Mexico City is located in the Valley of Mexico. Also known as the Valley of the Damned, it is a large valley in the high plateaus at the centre of Mexico. The Valley occupies 1300 $\mathrm{km}^{2}$ at a nominal elevation of $2240 \mathrm{~m}$ above mean sea level, and is bordered to the east and west by mountains that rise $1000 \mathrm{~m}$ above the valley floor, with low points to the north and south (Yip \& Madl 2002).

The earthquake prone area is surrounded by mountains on all four sides (amongst others the active volcanoes of Popocatepetl and Itzacehuatl), with only one small opening to the north. Thus, Mexico City combines natural hazards with enormous structural vulnerability due to explosive urban sprawl, population density, poverty, etc. (Taubenböck et al. 2008). 


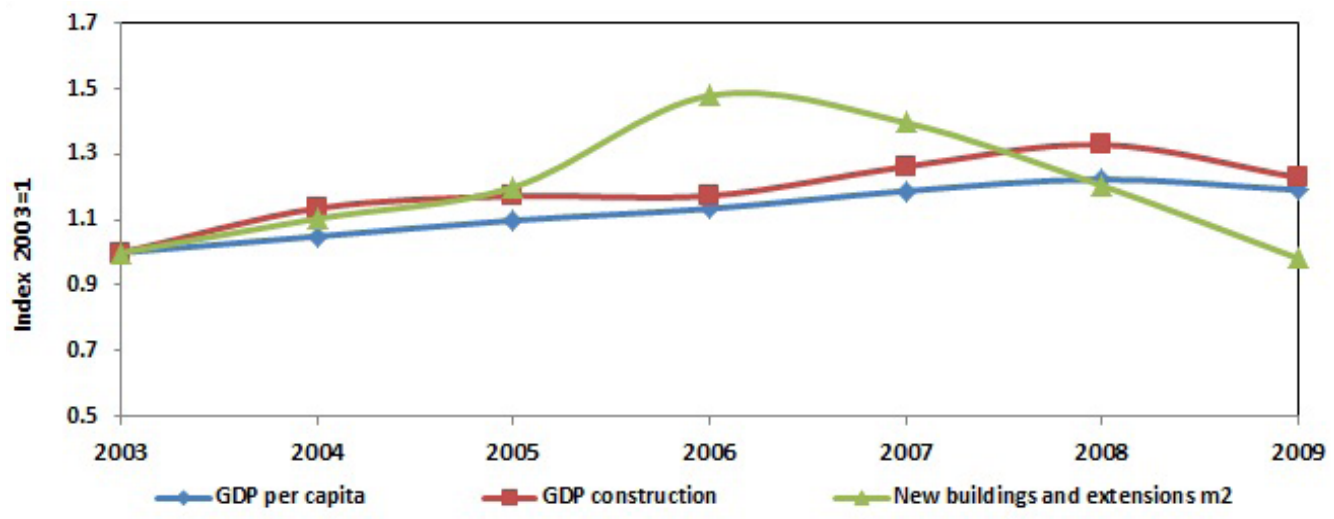

Figure 7. Santiago de Chile - Gross domestic products and new buildings and extensions Source: CEPAL Database 2014

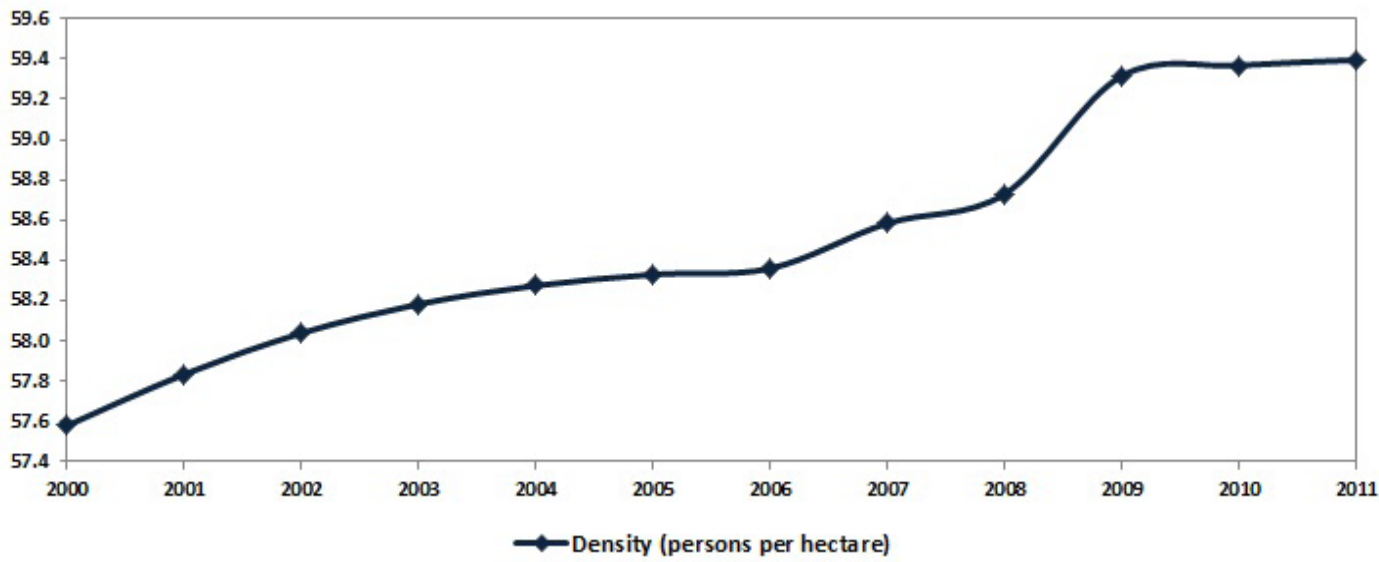

Figure 8. Mexico City - Urban density 2000-2011

Source: INEGI, 2011

Mexico City is one of the few cities of the world without a natural drainage outlet, being located in a closed basin on the flat bed of what was once a series of lakes. These were of varying depth depending on rainfall, most of which is concentrated in the five months between May and September and is highly variable from year to year (Connolly 2003). The city is built upon these lakebeds. Lake Chalco is situated on the southernmost sector of the Basin of Mexico; due to its immediacy to freshwater sources, Chalco has usually been less saline than other lakes within the basin (Brown et al. 2012).

\section{Urbanization trends}

The urbanization process took place at a great speed (mainly in the latter half of the twentieth century) in this city, changing its landscapes by expanding into the urban-rural periphery where the pattern of urbanization of the city is dispersed and chaotic due to the absorption of many rural areas. This expansion has had high social and environmental costs which increase social inequalities and the uneven provision of infrastructure, services, and urban equipment (Losada et al. 2000). During the period 1990-2000 the population in central Mexico City, including the Federal District of Mexico, increased by only $1.3 \%$, while the population at the periphery increased by $2.9 \%$ (Aguilar 2008; Wigle 2010). Moreover, the population of D.F. is now more than 8 million inhabitants whereas 20 million inhabitants live in the Mexico metropolitan area (Crotte et al. 2011).
These data indicate: a slower population growth in the city centre in comparison with the other parts of the city, and transference of population from the former to the latter; an expulsion of population from the historical city; a higher growth of the periphery which is twice that of the whole city; and an accelerated growth of the metropolitan periphery (Aguilar 2008).

Changes in land use and cover in urban areas of Mexico City have impacted the function and services of ecosystems which are key for the sustainability of the city, such as water, climate, food, and culture (Merlin et al. 2013). Moreover, the pattern of distribution of social classes is characterized by a periphery inhabited by lower classes and internal migrants displaced to these zones, whereas the privileged sectors inhabited the central areas. This trend generated a gradual consolidation of the more immediate peripheries and sustained expansion of the new periphery areas. Likewise, the most exclusive residential areas were displaced to the zone stretching from the city centre to the northwest (Bayón \& Saraví 2012).

The density of Mexico City has increased in the last decade (see Fig. 8) from 57.60 inhabitants per hectare in 2000 to 59.39 inhabitants per hectare in 2010. This city is ranked the third largest urban agglomeration to date around the globe, which generates natural hazards with enormous structural vulnerability due to explosive urban sprawl, population density and poverty, among others (Taubenböck et al. 2008). 


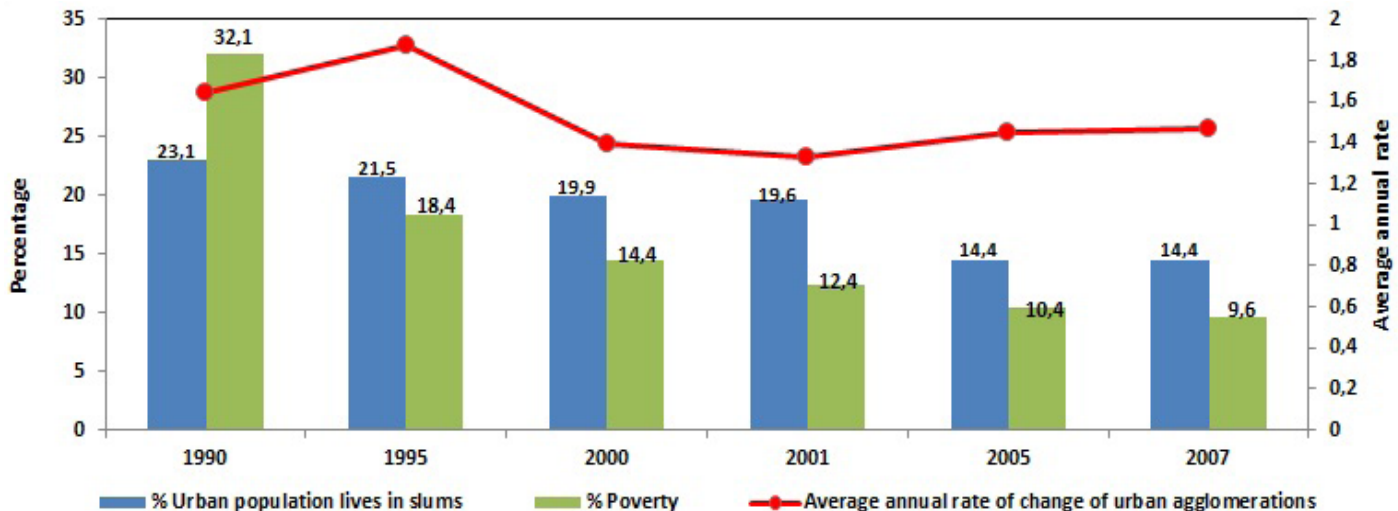

Figure 9. Mexico City - Slums, poverty and urban rate change Source: CEPAL Database 2014

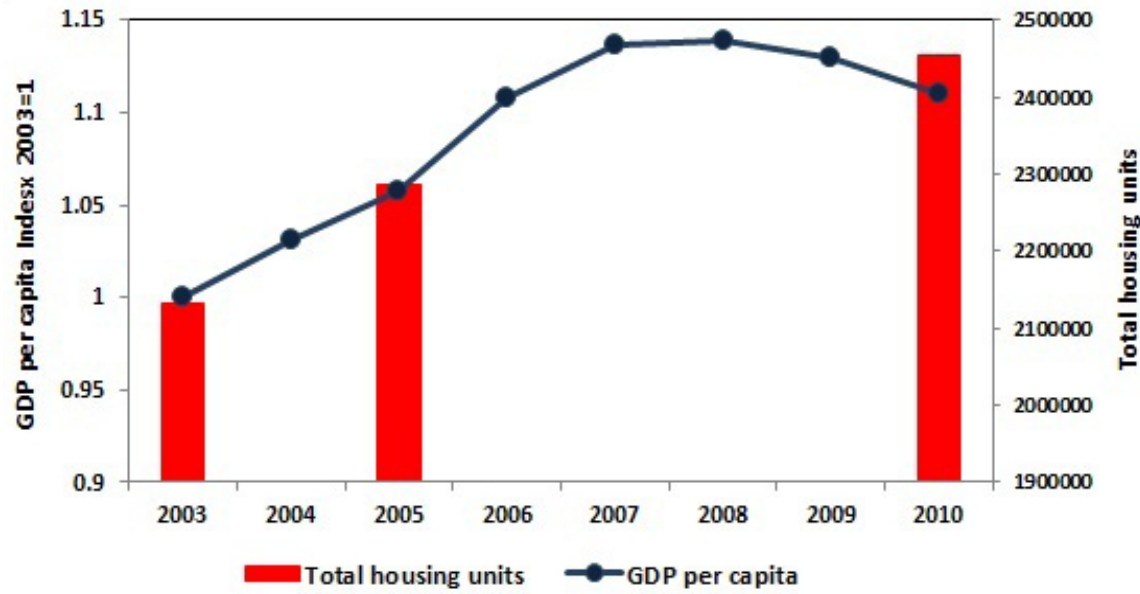

Figure 10. Mexico City - Total housing units and gross domestic product per capita

Source: CEPAL Database

Density for sub-urban areas according to the estimate of 3.3 persons per household is maintained at less than 20 households per hectare, indicating that in this city the formal process of suburbanization is fulfilled for the criteria of density and urban growth. However, the informal urban growth process shows an average density of 119 inhabitants per hectare (if every household has a family with 3.5 persons, the results will be 34 households per hectare).

\section{Urbanization and socioeconomic aspects}

Slums in this city are generated by illegality, including the following conditions: unauthorised land development, non-fulfilment and inexistence of building permits, initial and sometimes permanent lack of urban services, high risk of flooding, landslides or other hazards, dubious or inexistent original and subsequent property titles, and the operation of alternative property jurisdiction. Housing policy has addressed the regularisation of this housing which has achieved an improvement in infrastructure and facilities of those areas that is located around the city, demonstrated as periurbanization which is characterized by localization around the city as slums or lost cities.

Figure 9 shows the main trends of slums, poverty and rate of change of agglomeration in Mexico City determined by the trends in poverty and slums having a direct relationship whereas change of agglomeration has had a stable rate over the last decades. These results indicate that cities that achieve a decrease in slums also achieve a decrease in poverty and maintain a stable growth of the city.

Figure 10 shows the trends between gross domestic product and total housing units, demonstrating that these two indicators have a similar trend (concurring with Connoly (2003), who showed that cities generally grow cyclically, in accordance to the macroeconomic and social processes governing urban development). As a general rule, the city expands horizontally in times of recession, when land is cheap, and consolidates in times of economic growth when credit for building is available.

\section{Conclusions}

This paper analysed urban expansion in three cities of Latin America (Buenos Aires, Santiago de Chile and Mexico City), determining that the urbanization trend was maintained over recent decades in these cities, which has reconfigured the city system with urban growth patterns according to local considerations and similar dynamics.

The comparison of the cities analysed shows that urbanization phenomena are diverse, especially relating to urban expansion mechanisms on surrounding areas. Processes of sub urbanization and peri-urbanization ultimately lead to metropolitan and regional patterns. 
However, urban compositions are complex in the configuration of new urban networks where main cities give way to the consolidation of new urban centres which quickly achieve one million inhabitants and a sufficient density of basic urban services. The growth of intermediate cities generates other processes, such as suburbanization, peri-urbanization, and counter-urbanization, which is related in Latin America to the urbanization process and it is considered hidden urbanization.

In the three cities analysed, localization has been influenced by physical and geographic characteristics according to environmental features and utilities such as the close proximity of bodies of water, natural landscapes, mountain ecosystems and agricultural land. These factors lead to a high pressure on urban land, to conflicts between different land uses and to new risks which mean a series of environmental impacts and the reduction of environmental services caused by the urbanization process: increasing surface runoff and frequency and magnitude of natural hazards, decreasing groundwater recharge, polluted water sources, and the concentration of air and soil pollution.

The urbanization processes in the three cities studied show that recent decades have been characterized by a very rapid growth from central areas to periphery, which has substantially increased social segregation and socioecological fragmentation in the cities. This is a consequence of an explosive and nonplanned urbanization process, demonstrating that urban planning needs to be strategically assessed in economic, social and environmental terms with the aim of achieving sustainable cities in Latin America.

The results of urban densities, calculated in this study as population divided by urban total area, are generally lower because they include empty land where they should include the specific density for suburban areas, formal urban areas, and informal areas.

The population in Latin America has increased rapidly due to natural population growth and migratory flows from rural areas to intermediate cities and great metropolises, generating a physical expansion rather than demographic growth.

The transformation of metropolitan areas to urban regions generates intense physical expansion, socio-economic residential segregation, social inequality, metropolitan restructuring and new public policies on housing and employment.

Peri-urban areas are characterized by the highest dynamic of change due to migration of wealthy households seeking better quality of life and a natural landscape, and poor families who also seek these zones. However, these areas lack a consolidated infrastructure, urban equipment and basic services, generating a negative impact on quality of life for new settlers.

Urbanization and socioeconomic aspects show that in the three cities improvements in quality of life and income generate a decrease in slums and poverty, demonstrating that socioeconomic aspects have a direct relationship with urbanization where cities generally develop cyclically; in times of recession they expand horizontally when land is cheap, and consolidate in times of economic growth.

Latin America is becoming a more urban region, with high demands on public services, infrastructure and the labour market. However, this growth has generated environmental and social precariousness, violence, insecurity, and metropolitan segregation, which is likely to decrease opportunities in every city.

\section{References}

Aguilar, A 2008, 'Peri-urbanization, illegal settlements and environmental impact in Mexico City', Cities, vol. 25, pp. 133-145.

Alfonso, W \& Pardo, C 2012, 'The suburbanization process in Bogotá D.C. and municipalities of the Savanna of Bogotá 1998-2010' in Suburbanization versus peripheral sustainability of rural-urban areas fringes, eds M Czerny \& G Hoyos Castillo, NOVA Publishers, pp. 103-122.

Banzhaf, E Reyes-Paecke, S Müller, A \& Kindler, A 2013, 'Do demographic and land-use changes contrast urban and suburban dynamics? A sophisticated reflection on Santiago de Chile', Habitat International, vol. 39, pp. 179-191.

Borde, J 1966, Les Andes de Santiago et leur avant pays. Étude de géomorphologie, Union Française d'Impresion, Bordeaux.

Brüggen, J 1950, Fundamentals of the geology of Chile, Instituto Geográfico Militar, Chile (in Spanish).

Bayón, M \& Saraví, G 2012, 'The cultural dimensions of urban fragmentation segregation, sociability, and inequality in Mexico City', Latin American Perspectives, vol. 40, pp. 35-52.

Bijker, R \& Haartsen, T 2012, 'More than counter-urbanisation: migration to popular and less-popular rural areas in the Netherlands', Population, Space and Place, vol. 18, pp. 643-657.

Bochaca, F \& Puliafito, E 2007, 'Dry island effect on intermediate cities. The case of the city of Mendoza', in Urbanization, global environmental change, and sustainable development in Latin America, eds R Sanchez Rodriguez \& A Bonilla, São José dos Campos, Brazil, pp. 77-104. Available from: <http://www.iai.int/files/communications/publications/ institutional/Book_English.pdf>. [12 June 2013].

Borsdorf, A 2004, 'On the way to post-suburbia? Changing structures in the outskirts of Euopean cities', in Structures.
European Cities: Insights on Outskirts, eds A Borsdorf \& P Zembri, Paris, pp. 7-30

Brown, E, Werne, J, Lozano-García, S, Caballero-Miranda, M, Ortega-Guerrero, B, Cabral, E, Valero \& Schwalb, A 2012 'Scientific drilling in the Basin of Mexico to evaluate climate history, hydrological resources, and seismic and volcanic hazards', Scientific Drilling, vol. 14, pp.72-75.

Center for Social Research (CSR) 2007, National Cadastre of Encapment. Available from: <http://www.untechoparachile. $\mathrm{cl} /$ subsitios/cis/web>. [2 August 2013].

CEPAL, 2014, Latin-American Database Cepalstat. Available from: <http://estadisticas.cepal.org/cepalstat/ WEB_CEPALSTAT/estadisticasIndicadores.asp?idioma=e>. [25 June, September 2013].

Clark, J McChesney, R Munroe, D \& Irwin, E 2013, 'Spatial characteristics of exurban settlement pattern in the United States', Landscape and Urban Planning, vol. 90, pp. 178-188.

Connolly, P 2003, Urban Slums Reports: The case of Mexico City, Mexico. Available from: <http://www.ucl.ac.uk/dpuprojects/Global Report/pdfs/Mexico.pdf>. [27 August 2013]

Córdoba, J \& Gago, C 2010, 'Latin American cities and globalisation: change and permanency in the context of development expectations', Urban Studies, vol. 47, pp. 2003-2021.

Cravino, M 2006, Las villas de la ciudad. Mercado e informalidad urbana, UNGS, Los Polvorines.

Cravino, M 2011, 'Structural transformations of slums in Buenos Aires', Annual RC 21 Conference 2011. Available from: <http://www.rc21.org/conferences/amsterdam2011/edocs/ Session\%2029/RT29-1-Cravino.pdf>. [2 September 2013].

Crotte, A, Graham, J \& Noland, B 2011, 'The role of metro fares, income, metro quality of service and fuel prices for sustainable transportation in Mexico City', International 
Journal of Sustainable Transportation, vol. 5, pp. 1-24.

Dufour, D \& Piperata, B 2004, 'Rural-to-urban migration in Latin America: an update and thoughts on the model', American Journal of Human Biology, vol. 16, pp. 395-404.

Fernández, JC 2001, Environmental geological study for territorial planning of the Tiltil-Santiago area, Thesis, Department of Geology, University of Chile (in Spanish).

Ferras, C 2007, 'El enigma de la contraurbanización. Fenómeno empírico y concepto caótico', EURE (Santiago), no. 98, May.

Fourcat, A 1996, 'Lotissements, mal lotis et crise urbaine en banlieue dans I'Entre-deux-guerres', Cities, Villes, Ciudades, junio, pp. 15-17, París, PIR-Villes.

Fundación Bariloche (FB) 2008, 'Urban and Periurban Energy Access - UPEA II. Buenos Aires Case Study', Final Assessment Revised Draft Report, Global Network on Energy for Sustainable Development - GNESD Facilitated by UNEP.

Gans, P 2007, 'Internal migration patterns in the EU and the future population development of large cities in Germany', presentation at the international seminar Migration and Development: the case of Latin America, Santiago, Chile, 7-8 August. Available from: <www.eclac.org/celade/noticias /paginas/7/29527/Gans.pdf>. [2 June 2013].

Garreau, J 1991, Edge City - life on the new frontier, Doubleday, New York.

Gorelik, A 1998, La grilla y el parque. Espacio público y cultura urbana en Buenos Aires, 1887-1936, Universidad Nacional de Quilmes, Buenos Aires.

Gobierno de la ciudad de Buenos Aires (GCBA) 2011, Banco de datos de la Ciudad de Buenos Aires. Available from: <http:// www.estadistica.buenosaires.gob.ar/areas/hacienda/ sisestadistico/>. [25 July 2013].

Hidalgo, R \& Borsdorf, A 2009, 'European urban growth: concepts, trends and a comparative framework for the metropolitan area of Santiago de Chile', Estudios Geográficos, vol. LXX, pp. 181-203.

INE (Instituto Nacional de Estadísticas) 2011, Censo de Población y Vivienda 2011, Santiago de Chile.

INEGI (Instituto Nacional de Estadística y Geografía) 2011, Censo de Población y Vivienda, México.

Inostroza, L Baur, R \& Csaplovics, E 2013, 'Urban sprawl and fragmentation in Latin America. A dynamic quantification and characterization of spatial patterns', Journal of Environmental Management, vol. 115, pp. 87-97.

Klaufus, C 2010, 'Watching the city grow: remittances and sprawl in intermediate Central American cities', Environment and Urbanization, vol. 22, pp. 125-137.

Krellenberg, K, Müller, A, Schwarz, A, Höfer, R \& Welz, J 2013, 'Flood and heat hazards in the Metropolitan Region of Santiago de Chile and the socio-economics of exposure', Applied Geography, vol. 38, pp. 86-95.

Leston, E 2005, 'Urban mutations in the Buenos Aires metropolitan area', Holcim Foundation for Sustainable Construction. Available from: <http://src.holcimfoundation. org/dnl/eb95b2f3-7978-48cb-89d8-d80fd66fa168/leston. pdf>. [8 July 2013].

Licínio, A, Freitas, A, Evangelista, H, Costa-Gonçalves, A, Miranda, M \& Alencar, A 2013, 'A high spatial resolution outdoor dose rate map of the Rio de Janeiro city, Brasil, risk assessment and urbanization effects', Journal of Environmental Radioactivity, vol. pp. 126, 32-39.

Losada, H, Bennett, R, Soriano, R, Vieyra, J \& Cortés, J 2000, 'Urban agriculture in Mexico City. Functions provided by the use of space for dairy based livelihoods', Cities, vol. 17, pp. 419-443.

Ministry of Housing and Urban Affairs (MHUA) 2006, Atlas of evolution of the housing déficit in Chile. 1992-2002, Santiago: Ministry of Housing and Urban Affairs.
Merlín, Y, Contreras, A, Astier, M, Jensen, O, Zaragoza, R \& Zambrano, L 2013, 'Urban expansion into a protected natural area in Mexico City: alternative management scenarios', Journal of Environmental Planning and Management, vol. 56, pp. 398-411.

Nieves, M 2006, 'Buenos Aires, Cultural Landscape: The river; the pampas, the historical ravine and immigration', United States National Committee of the international Council on Monuments and Sites. $9^{\text {th }}$ US/ICOMOS International Symposium.

Osada, S 2003, 'The Japanese urban system 1970-1990', Progress in Planning, vol. 59, pp. 125-231.

Pacione, M 2009, Urban geography. A global perspective, Routledge.

Parnreiter, C 2004, 'Zwischen hoher Verstädterung und neuer ländlicher Entwurzelung. Migration in Lateinamerika', Praxis Geographie, vol. 78, pp. 34-37.

Poelhekke, S 2011, 'Urban growth and uninsured rural risk: Booming towns in bust times', Journal of Development Economics, vol. 96, pp. 461-475.

Rojas, C, Pino, J \& Jaque, E 2013, 'Strategic environmental assessment in Latin America: A methodological proposal for urban planning in the Metropolitan Area of Concepción (Chile)', Land Use Policy, vol. 30, pp. 519-527.

Romero, H, Vásquez, A, Fuentes, C, Salgado, M, Schmidt, A \& Banzhaf, E 2012, 'Assessing urban environmental segregation (UES). The case of Santiago de Chile', Ecological Indicators, vol. 23, pp. 76-87.

Romero, H \& Ordenes, F 2004, 'Emerging Urbanization in the Southern Andes Environmental Impacts of Urban Sprawl in Santiago de Chile on the Andean Piedmont', Mountain Research and Development, vol. 24, pp. 195-199.

Taubenböck, H, Eschb, T, Wurma, M, Thielb, M, Ullmannb, T, Rotha, A, Schmidta, M, Mehla, H \& Dech, S 2008, Urban structure analysis of mega city Mexico City using multisensoral remote sensing data. Available from: <http://elib. dlr.de/59012/1/7110_13.PDF>. [13 August 2013].

Torres, H 1993, El mapa social de Buenos Aires (1940-1990), Buenos Aires, Secretaría de Investigación y Posgrado/ Facultad de Arquitectura, Diseño y Urbanismo, serie Difusión núm. 3.

Thiele, R 1980, 'Santiago Sheet, Metropolitan Region', Chile Geological Sheet, vol. 29, Servicio Nacional de Geología y Minería, Santiago (in Spanish).

Thomas, H 1958, 'Geology of the Coastal Cordillera between the La Ligua Valley and Barriga Hill', Instituto de Investigaciones Geológicas, Santiago, Bulletin 2 (in Spanish).

United Nations Human Settlements Programme (UN-Habitat) 2012. The State of Latin American and Caribbean Cities 2012. Towards a new urban transition. Available from: $<w w w . u n h a b i t a t . o r g>$. [9 August 2013].

Valenzuela, G 1978, 'Foundation Soils of the Great Santiago', Instituto de Investigaciones Geológicas, Santiago, Bulletin 33 (in Spanish).

Virgilio, M \& Vio, M 2009, La geografía del proceso de formación de la región metropolitana de buenos aires. Available from: <http://www.lahn.utexas.org/Case \%20Study\%20Cities/ Innerburb/BA/Urbaniza cionAMBA.pdf>. [25 May 2013].

Weiland, U, Kindler, A, Banzhaf, E, Ebert, A, Reyes-Paecke \& S 2011, 'Indicators for sustainable land use management in Santiago de Chile', Ecological Indicators, vol. 11, pp. 10741083.

Wigle, J 2010, 'The 'Xochimilco model' for managing irregular settlements in conservation land in Mexico City', Cities, vol. 27, pp. 337-347.

Yip, M \& Madl, P 2002, Air Pollution in Mexico City. Available from: <http://biophysics.sbg.ac.at/mexico/air.htm>. [23 September 2013]. 